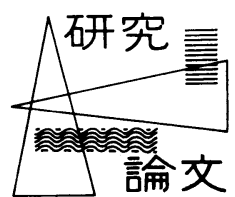

\title{
ディーゼル燃焼に対する燃焼室形状の影響 （高過給四サイクル中速機関による実験結果）*
}

\author{
下津 正 輝 $^{* *}$. 下中利 康 $^{* * * *}$ \\ 須間俊 明 ${ }^{* * * *}$ 平田修三***
}

\author{
A Study on the Effects of the Chamber Walls \\ on the Diesel Combustion Phenomena \\ (Test Results of Highly Supercharged 4-Cycle \\ Medium-Speed Diesel Engine)
}

By Masateru Shimotsu, Toshiyasu Shimonaka, Toshiaki Suma, Shuzo Hirata

The combustion chamber plays an important role in the fuel-air mixing process and resultant fuel spray pattern which have a large influence in a diesel engine. Furthermore, the chamber wall cools off the gas in the combustion chamber and quenches the combustion zone, thus the thermal efficiency and the combustion efficiency of an engine would be lower.

In order to investigate the effect of the combustion chamber shape on the engine performance, the authors conducted some experiments using a single cylinder 4-cycle test engine and a test equipment. Piston crown shape, combustion chamber height, number of fuel nozzle holes, direction of fuel nozzle hole and charge air pressure were chosen as the experimental factors.

From the results, it is confirmed that the fuel mixing process with surrounding gas is mainly done by the mobility of the fuel spray. Therefore, it was concluded that the interference of the chamber wall in the motion of the fuel spray must be avoided especially on the early stage of the spray travel.

Based on the results, then the authors redesigned the piston crown of their 4-cycle medium-speed diesel commercial engine, and confirmed the improvement of the combustion performance.

\section{1.はじめに}

ディーゼル機関の燃焼は，熱効率などの経済的な面や， $\mathrm{NO}_{\mathbf{x}}$ やすすの排出量といった環境面に大きく影響する. その現象は非常に複雑で, それを左右する因子は, 燃料 系因子や，燃焼室内のガス流動因子など多岐にわたって おり，本報で取り上げた燃焼室形状因子は，それらの中 で最も重要なものの一つである.その影響としては，ま ず燃焼室壁は燃料噴霧や周囲気体の運動に干渉して，そ れらの混合過程そして燃焼過程に影響する. 高速ディー ゼル機関では，種々の燃焼室形状が実用されており，燃 焼性能の改善に寄与している. また燃焼室壁は，燃焼室 内気体や燃焼域そのあのを泠却するととにより, 冷却損

\footnotetext{
* 原稿受付 昭和 59 年 12 月 1 日 昭和 59 年秋季学術講演(昭和 59 年 10 月 24 日)

** 正会員 三井造船(株)玉野研究所(玉野市玉原 3-16-1)

*** 正会員 三井造船(株)玉野事業所(玉野市玉 3-1-1)

****三井造船(株)玉野事業所(玉野市玉 3-1-1)
}

失の増大や不完全燃焼物質の排出量の増加をむたらすと 考えられる.

このような現象を解明するために，従来から多くの研 究成果が報告されている. 国吉ら ${ }^{1)}$, Lustgarten $^{2)}$, 常 本ら ${ }^{3)}$ は, 冷間非燃焼状態で燃料噴霧を燃焼室模型内に 噴射し，壁面に影響された燃料噴霧の挙動を観察した。 そしてその結果から燃料の分散に対する壁面の影響や， 壁面での燃料付着について考察を加えている. 広安ら ${ }^{4)}$, 堀 ${ }^{5,6)}$ は機関実験により燃料噴霧が燃佬室壁に衝突する ことの混合気形成や着火遅れ，初期燃焼への影響を調べ ている. 長尾, 池上ら ${ }^{7 \sim 9)}$ は種々の形状の燃焼室を実験 用機関に適用して高速度撮影により燃焼域の大きさの時 間変化などを観察し，それと機関性能の関連を報告して いる. 神本, 青柳 ${ }^{10,11)}$ は, 燃焼室形状による燃焼性能 や排ガス成分の変化を調べた. しかしてれらの研究のほ とんどは小形高速機関に対するものであって，中形機関 についてはKawakami ら ${ }^{12)}$ の報告などわずかである. そこで著者らは，高過給四サイクル中速機関の燃焼性 
能の改善を目的として, 単気筒機関を用いて, 燃焼室形 状の変化に伴う機関性能の変化を調べるとともに，常温 高圧下の静止気体中に噴射された壁面衝突噴霧に関する 実験を行った，実験因子は，ピストン冠の形状，燃焼室 の高さ, 燃料弁噴孔数, 燃料噴射方向角及び給気压であ る. これらの実験の結果, 機関の燃焼性能を改善する要 件である燃料の分散度の改善は, 燃料噴霧が有する周囲 気体に対する相対運動能力を，できるだけ長期間温存す るととによって達成されるととがわかった.したがって， 燃料弁近傍では燃料噴霧の運動速度が大きく，噴霧円錐 部からの周囲気体の流入も盛んであるため, 燃焼室の高 さをある程度確保して，噴霧に対する燃焼室壁の干渉を できるだけ避けたほうが良いと考えられる．以下に詳細 を報告する.

\section{2. 供試機関を用いた実験}

2.1 実験装置 供試機関の主要目を表 1 に示す. この機関は単気筒であるため, 過給用に独立の送風系統 をそなえている. 図 1 にそれを示す。過給圧は四中の調 圧器で所定の值に設定できる. 供試機関への送風量は, オリフィスで計測する. 本実験の計測項目と, 計測方法 はつぎのとおりである.

燃焼室内圧は，ピエゾ型圧力ピックアップを使用し， 増幅器を経てデスクトップコンピュータで制御される高 速データ収録装置により, ディジタル化して計測した. 燃料噴射圧は, 燃料弁と燃料高圧管の連結部に歪ゲージ 型圧力センサーを取付け, 動歪計, 増幅器を経て燃焼室 内圧と同時に同様の方法で計測した. これらはいずれも， クランク角度で 1 度どよに 128 サイクル積算し, その平 均から 1 サイクルの王力パターンを求めた. 燃料噴射の 開始及び終了の時期は, 渦電流型変位計により燃料弁針 弁の動きを検出して決定した. 排煙濃度は, 排気 3 リッ トルを濾紙を通過させ，その濾紙の黒さをスモークメー タで計測することによりボッシュインデックスとして求 めた。

実験に使用した燃焼室の形状は 3 種類で, ピストン TDC状態での断面形状を図 2 に示す. 3 種ともカバー 側形状は同じである. 1 型燃焼室は，ピストン側を円錐 台状にしたもの，2 型は一つの円形平板状にしたもの, 3 型は外周に土手を付けて，いわゆる浅皿状にしたもの である. 図からわかるように, 燃料弁近傍での燃焼室高 さは, 燃焼室容積を同一にすると, 1 型燃焼室が最小で

\section{表 1 供試機関主要目}

\begin{tabular}{|c|c|c|c|c|}
\hline \multicolumn{2}{|c|}{ 機 関 諸 元 } & \multicolumn{2}{|c|}{ 運 } & 元 \\
\hline 気 筒 数 & 1 & 定格回転数 & $\mathrm{rpm}$ & 530 \\
\hline 気 筒 径 $\phi \mathrm{mm}$ & 420 & 燃焼最高圧 & ata & $131.03\{12.84 \mathrm{MPa}\}$ \\
\hline ピストン行程 $\mathrm{mm}$ & 450 & 平均有効圧 & at & $20\{1.96 \mathrm{MPa}\}$ \\
\hline 有効圧縮比 & 11.6 & 給 気 圧 & ata & $2.92\{0.286 \mathrm{MPa}\}$ \\
\hline 吸排気弁数 & 各 2 & 軸 出 力 & PS & $715 \quad\{526 \mathrm{~kW}\}$ \\
\hline
\end{tabular}

Journal of the M.E.S.J., Vol.20, No.4

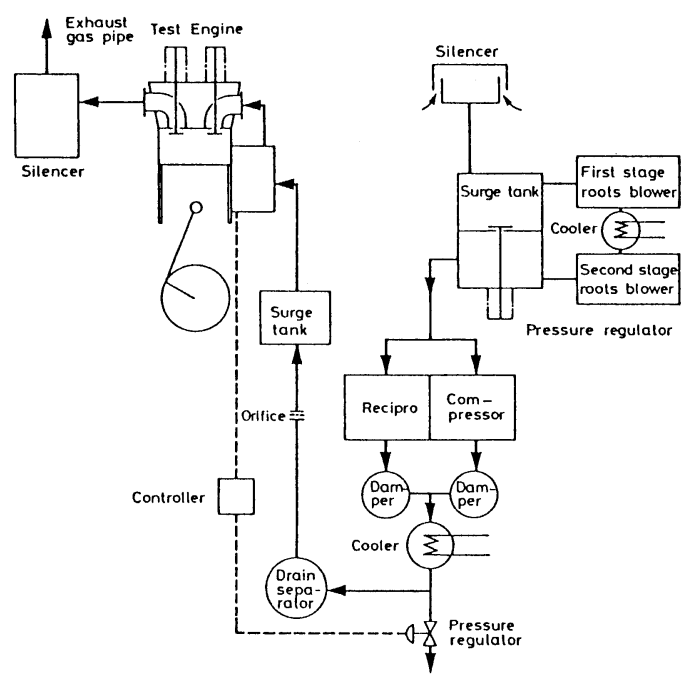

四 1 送風系統図
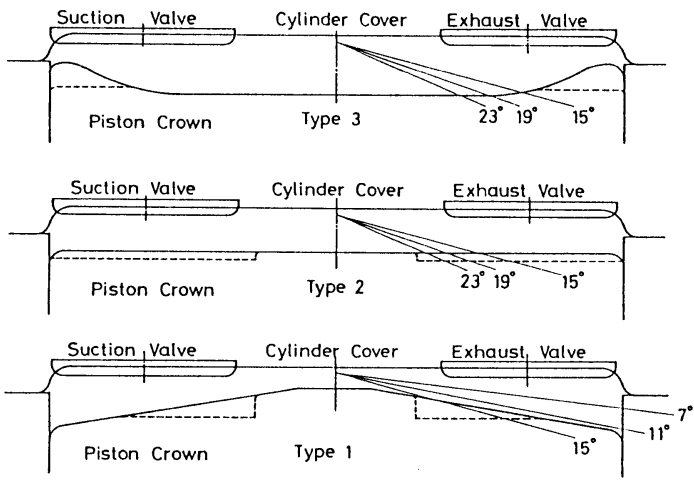

図 2 供試燃焼室形状

あり，3 型燃焼室が最大になっている．これらの燃焼室 は，いずれの場合もガス交換過程でピストンと吸排気弁 が衝突するのを避けるために，その逃げをピストン側に 切り込んでいる. 怄中の破線は，その切り込みを意味す る. 忷中の角度は，静止状態での供試燃料噴射方向を示 す.との汹から噴霧円錐角を考慮すると, 燃料弁から噴 出した燃料噴霧が最も早く燃焼室壁に衝突するのは 1 型 燃焼室の場合であり，最も遠くまで自由に運動できるの は，3 型燃焼室の場合であるととが想像される.

2.2 実験方法 実験は2 段階に分けて行った. ま ず闵 2 の 3 種の燃焼室形状之, 燃料弁噴孔数, 燃料噴射 方向角の 3 個を実験因子とする燃焼性能試験 を行った. この実験の実験点数は 27 点で, 各実験点での燃料弁の仕様は表 2 のとおりで ある. 供試機関の運転条件は，表 1 に合わせ た.また，燃焼室形状ごとに圧縮比が変化す るのを避けるために，ピストンTDC時の燃 焼室容積が同一になるように，連接棒の長さ （通常 $1080 \mathrm{~mm}$ ）を調節した。 
表 2 燃焼性能試験の燃料弁仕様

\begin{tabular}{|c|c|c|c|c|c|}
\hline \multicolumn{2}{|c|}{1 型燃焼室 } & \multicolumn{2}{|c|}{2 型燃焼室 } & \multicolumn{2}{c|}{3 型燃焼室 } \\
\hline 噴射角 & 噴孔数 & 噴射角 & 噴孔数 & 噴射角 & 噴孔数 \\
\hline 15 & 8 & 23 & 8 & 23 & 8 \\
15 & 9 & 23 & 9 & 23 & 9 \\
15 & 10 & 23 & 10 & 23 & 10 \\
11 & 8 & 19 & 8 & 19 & 8 \\
11 & 9 & 19 & 9 & 19 & 9 \\
11 & 10 & 19 & 10 & 19 & 10 \\
7 & 8 & 15 & 8 & 15 & 8 \\
7 & 9 & 15 & 9 & 15 & 9 \\
7 & 10 & 15 & 10 & 15 & 10 \\
\hline
\end{tabular}

つぎに 3 型燃焼室を用いて，連接棒の長さを変更する ことにより, TDC時の燃焼室高さを変化させ, 燃焼室 高さが燃料噴霧の燃焼によ゙う影響するかを調べた.

なお，いずれの実験もスワールのない条件で行った.

2.3 実験結果図3は, 表 1 の条件で, 図20燃 焼室形状を用いて, 表 2 の実験表により行った燃焼性能 試験の結果の中から, 燃料消費率の変化量 $\Delta B_{\mathrm{e}}$ 之, 排煙 濃度を示したものである.いずれの性能因子を見てあ， 害験範囲は，それぞれの燃焼室形状に対する最良点を含 んでおり，それは，どの燃焼室形状においてあ9 孔で実 現されている.

全体的に見て, 1 型燃焼室は他の 2 種の燃焼室に比較 して極端に性能が悪い。 また， 1 型燃焼室は他の燃焼室 より燃料噴射角に対する燃費性能の変化が大きい.

2 型燃焼室と 3 型燃焼室を比較すると, 燃料噴射角 15 度の場合は機関性能にほとんど差がない.しかし，さら に燃料噴射角がピストンの方を向いた場合, 2 型燃焼室 では燃費性能がどんどん悪くなるのに比べて，3 型燃焼 室では一旦良くなってから悪くなる傾向が見られ, 両燃 焼室の間に傾向の相違が見られる.

図 4 a, b, c は, 3 種の燃焼室におけるそれぞれの最

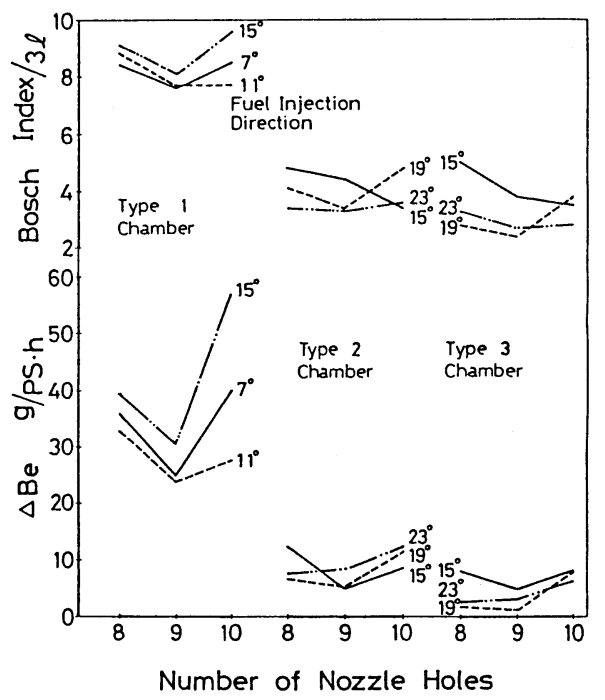

図 3 燃焼室形状と機関性能

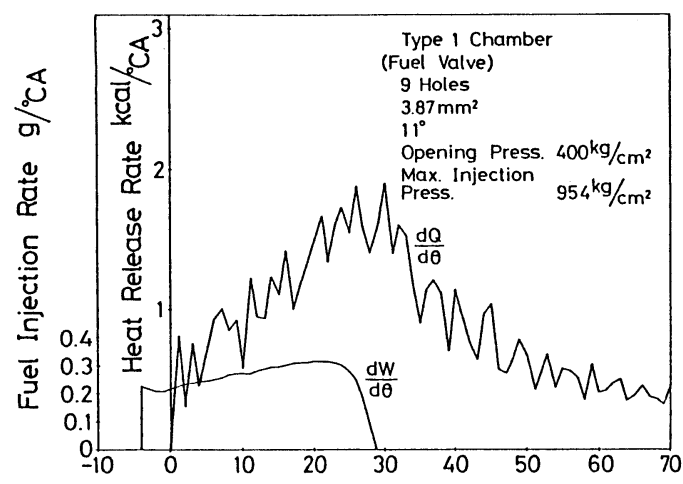

Crank Angle From Heat Release Initiation 'CA

困 $4 \mathrm{a}$ 燃料噴射率と熱発生率 (1 型燃焼室)

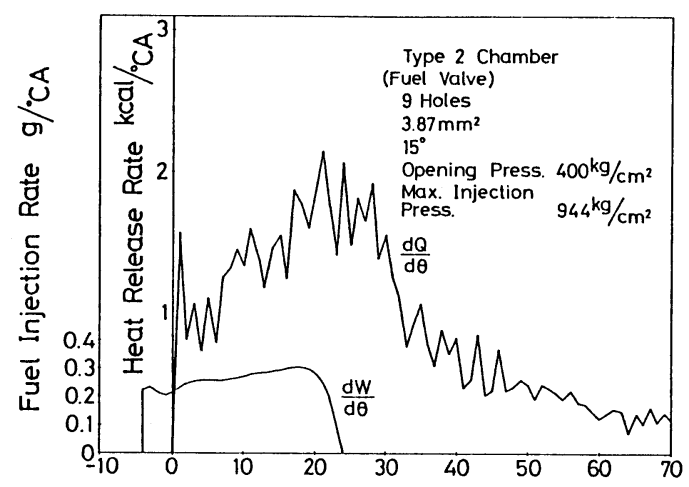

Crank Angle From Heat Release Initiation ${ }^{\circ} \mathrm{CA}$

困 4 b 燃料噴射率と熱発生率 (2 型燃焼室)

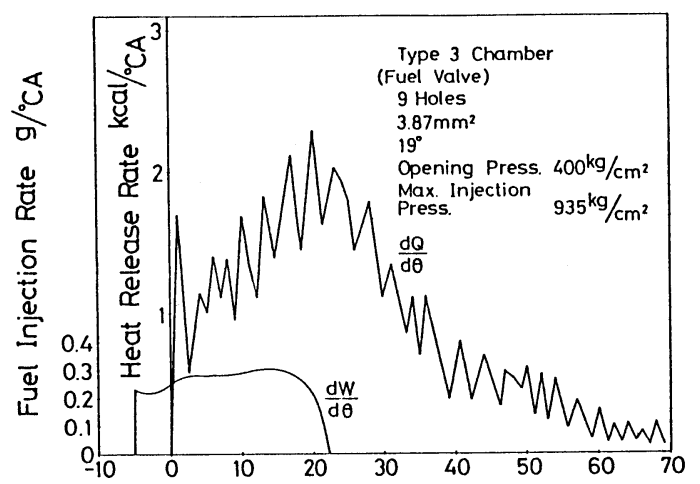

Crank Angle From Heat Release Initiation ${ }^{\circ} \mathrm{CA}$

図 $4 \mathrm{c}$ 燃料噴射率と熱発生率 (3 型燃焼室)

良燃費性能の場合について燃料噴射率と熱発生率の時間 変化をプロットしたものである. 1 型燃焼室は他の燃焼 室に比べて熱発生率が燃焼の初期から低く，後然えが多 い. 燃焼の初期から熱発生率が大きいのは 3 型燃焼室で あり，第 1 期の予混合燃焼期の熱発生率も 3 型燃焼室が 最大値を示す. 着火遅れ期間に関しては, いずれの燃焼 室に拀いても有為な差は認められなかった。 


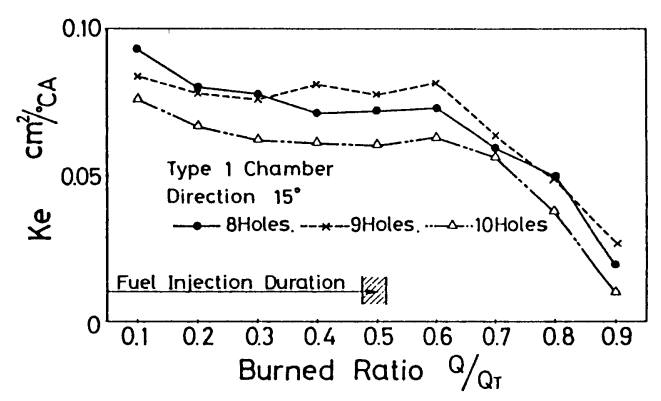

図 5 噴孔数による $K_{\mathrm{e}}$ パターンの変化

本実験に使用した燃料系は，燃料弁の燃料噴射方向角 以外全く同一のものを使用したととから燃料噴射率は， 3 種の燃焼室全部でほぼ同一の時間変化を示すが，燃料 噴射期間は，平均有効圧を一定とする実験を行ったので， 燃料消費率の良否に応じて変化する.

ここで，燃焼室形状の違いによる燃料噴霧の燃焼の違 いを明確にするため，著者らの一人が提案 ${ }^{13)}$ した燃料噴 霧の有効燃焼速度係数 $K_{\mathrm{e}}$ を用いて調へてみる. $K_{\mathrm{e}}$ は熱 発生率之燃料噴射率から末尾に示す方法で計算される.

図 5 は, 1 型燃焼室の場合について燃料弁噴孔数の違 いによる $K_{\mathrm{e}}$ パターンの違いをプロットしたあのである. 横軸には燃焼率 $Q / Q_{\mathrm{T}}$ をとった。ここで $Q ， Q_{\mathrm{T}}$ は，任 意のクランク角までに発生した熱量の積算值, 及び 1 サ イクルあたり総発熱量をそれぞれ示す．乙の図の場合， $K_{\mathrm{e}}$ の最大值は喷孔数がいずれの場合にも燃焼の極く初 期に出現しており，燃焼が進むとともに $K_{\mathrm{e}}$ は低下してい る. 燃焼の前期を除いて，9 孔が最も燃焼速度が高く， 10 孔の場合は常に $K_{\mathrm{e}}$ 值が小さくなっている.

$K_{\mathrm{e}}$ パターンと機関性能の関係については, 著者らがす でに詳細な報告 ${ }^{14)}$ をているが，それによると燃燒速度 $K_{\mathrm{e}}$ 值の低下，特に燃焼後半における低下は燃料消費率 を悪化させる. 図 3 と図 5 の結果の関係は，その結論之 同一の傾向を示している.

困 $6 \mathrm{a}, \mathrm{b}, \mathrm{c}$ に, 燃焼室形状ごとに, 燃料噴射角によ る $K_{\mathrm{e}}$ パターンの変化を示す. 図 $\mathrm{a}, \mathrm{b}, \mathrm{c}$ を比較すると, まず $\mathrm{a}$ 図の 1 型燃焼室だけは前述のように $K_{\mathrm{e}}$ 值の最高 值が燃焼の初期にあるが，他の二つの燃焼室の場合には， 燃焼開始後徐々に燃焼速度が高くなっている. この傾向は 2 型燃焼室より 3 型燃燒室の方が顕著である．そして燃 料噴射終了後に急速に燃焼速度が低下している. $K_{\mathrm{e}}$ 值 の全体的なレベルは 1 型燃焼室が最も低く，3 型燃焼室 が最も高くなっている．てのように熱発生率パターンよ りあ $K_{\mathbf{e}}$ パターンの方が燃焼室ごとの燃焼の違いをよりは っきりあらわすととができる.

2.1 節及び本節の結果から, 燃料噴霧が噴孔から噴出 した後,ピストンに衝突するまでの飛行距離が短く、燃 焼室壁の干涉を早くから受ける場合は，燃焼速度が高く ならず，燃料消費率が悪化するものと解釈される.

つぎに 3 型燃焼室を用いて，燃焼室の高さを変えて行

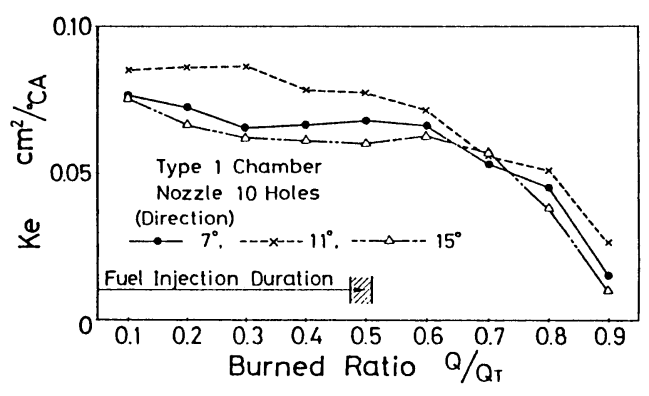

図 $6 \mathrm{a}$ 噴射方向角による $K_{\mathrm{e}}$ パターンの変化 ( 1 型燃焼室)

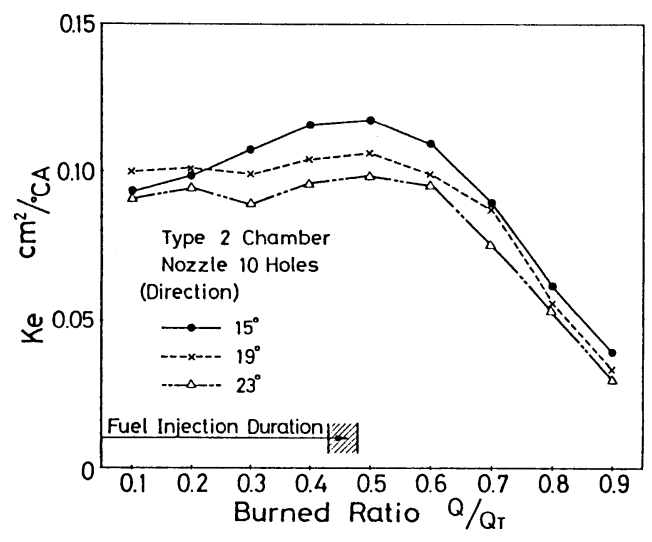

図 $6 \mathrm{~b}$ 噴射方向角による $K_{\mathrm{e}}$ パターンの変化 (2 型燃焼室)

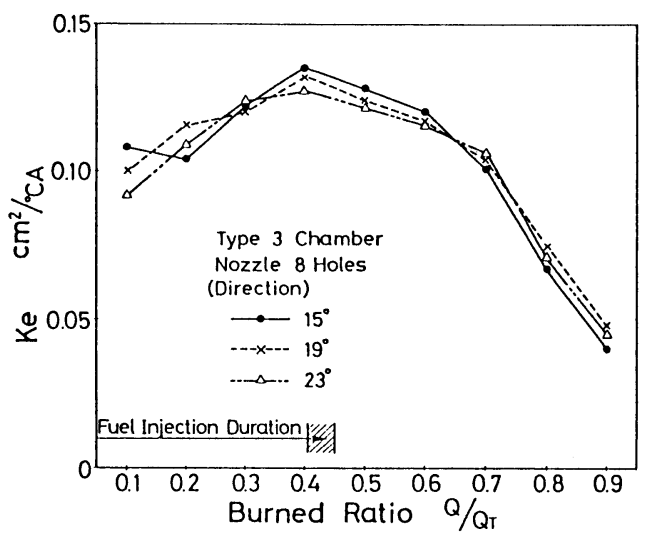

図 $6 \mathrm{c}$ 噴射方向角による $K_{\mathrm{e}}$ パターンの変化 (3 型燃焼室)

った燃焼実験の結果から燃料噴霧の燃焼速度 $K_{\mathrm{e}}$ のパタ ーンの違いを図7亿示す.との実験での機関運転条件は, 給気圧以外は表 1 のとおりである. またての実験では， 圧縮比之燃焼室内空気量が変化するのを避けるために吸 気弁開閉時期之給気圧を調節した。

図 $7 \mathrm{a}$ は, 3 水準の燃焼室の高さに対し，下向き 11 度 の方向に燃料を噴射した場合である．図中の $V_{\mathrm{T}}$ はTDC 


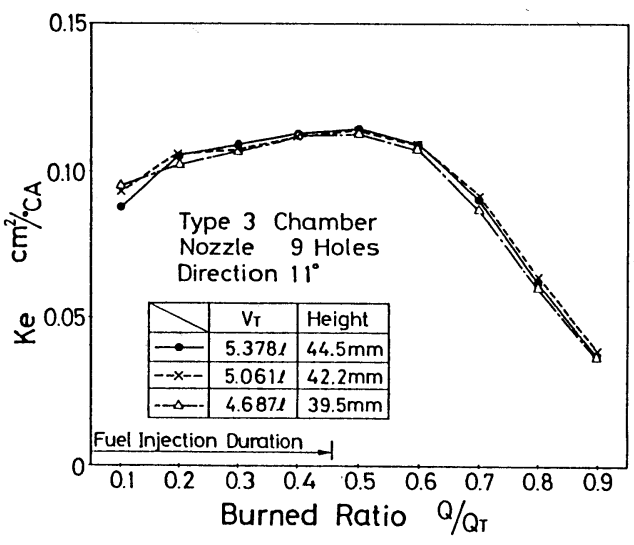

図 $7 \mathrm{a}$ 燃燒室高さの違いによる $K_{\mathrm{e}}$ パターン の変化(噴射方向角 11 度の場合)

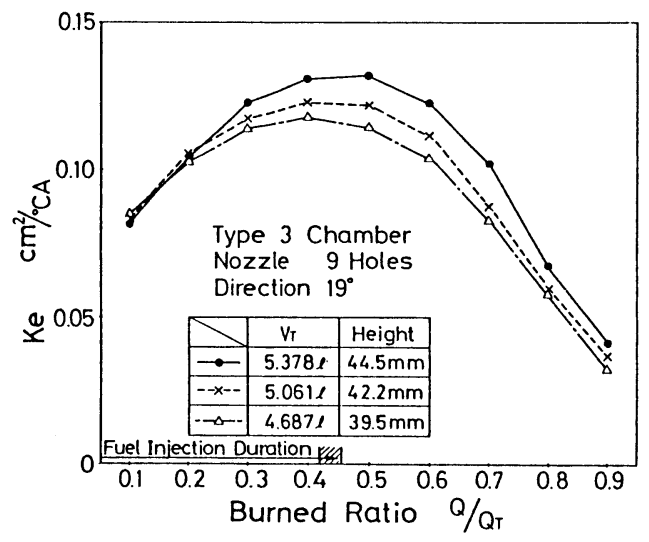

図 $7 \mathrm{~b}$ 燃焼室高さの違いによる $K_{\mathbf{e}}$ パターン の変化 (噴射方向角 19 度の場合)

時の燃焼室容積, Hight はその時の燃料弁近傍の燃焼室 高さを意味する，図から明らかなように，燃料噴霧の燃 焼に対する燃焼室高さの影響は，ほとんど現れていない， つまり，11度の方向に燃料を噴射した場合，ピストンは 燃焼を左右するほどの干涉を噴霧に及ぼさなかったもの と考えられる. 3 型燃焼室に対して実験範囲内で図 2 の ようにピストンTDCに抢ける燃料噴射方向を描くと， 噴霧はピストンに衝突することになるが，長尾，池上ら ${ }^{9)}$ の実験では，ピストンの動きによる気流のため燃料噴霧 が多少カバー方向に吹き上げられる現象が報告されてお り，11 度方向に噴射された噴霧はピストンに大きくはあ たっていない可能性もある.

てれに対して燃料噴射角をさらに 8 度ピストン側に向

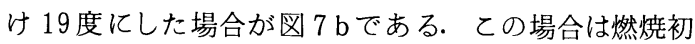
期には，燃焼室の高さの影響は見られないが，その後は 燃焼室の高さが小さくなるに従って燃焼が悪化したこと がわかる.これは, 燃料噴霧がピストンと衝突し，その 衝突までの自由飛行距離が，燃焼室の高さが低くなるに 従って短くなっているためであると解釈される.

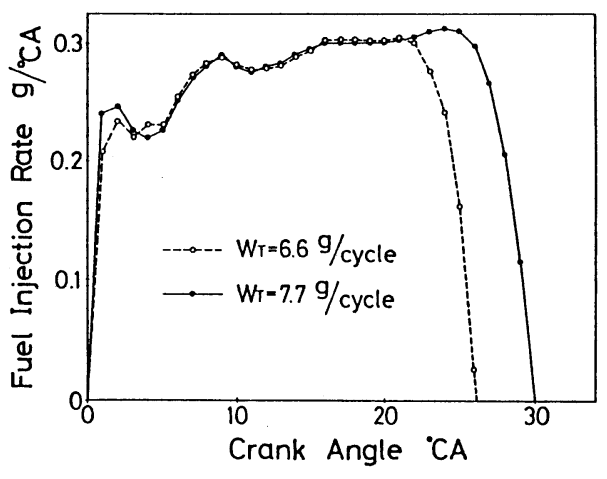

困 8 供試燃料噴射率パターン

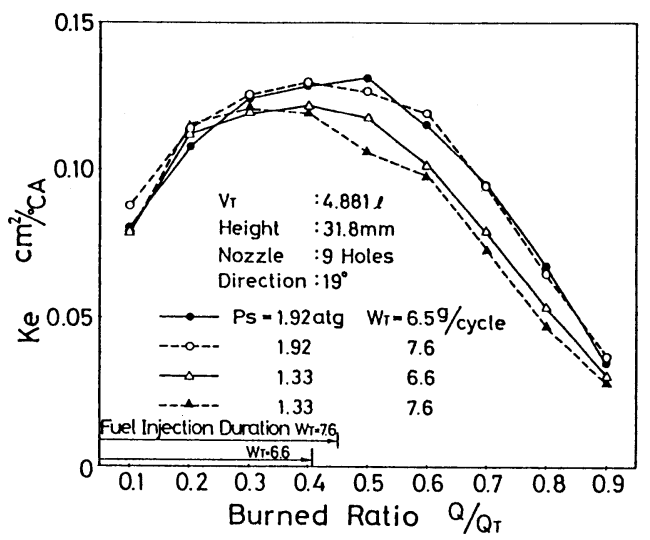

区 $9 \mathrm{a}$ 燃料噴射量の違いによる $K_{\mathrm{e}}$ パターン の変化 (燃焼室高さが低い場合)

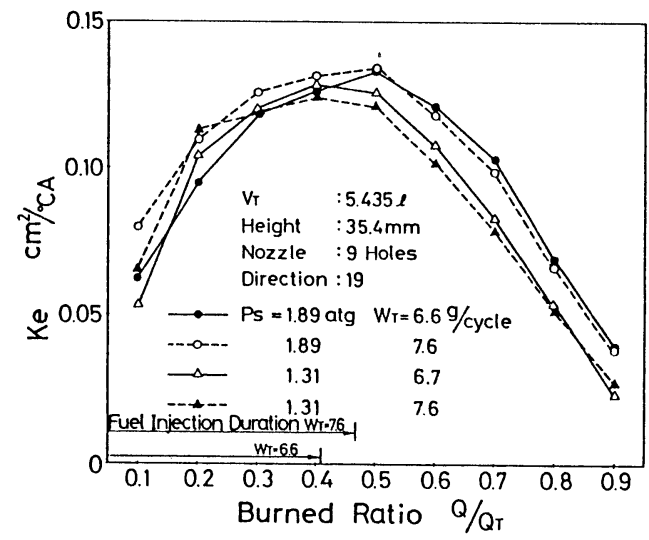

図 $9 \mathrm{~b}$ 燃料噴射量の違いによる $K_{\mathrm{e}}$ パターン の変化 (燃焼室高さが高い場合)

図 $9 \mathrm{a}, \mathrm{b}$ は，供試機関に図 2 の 3 型燃焼室を装着し， 1 サイクルあたりの燃料噴射量を変化させて, その $K_{\mathrm{e}}$ パ ターンに対する影響を調べた結果を示す. 四中の $P_{\mathrm{s}}$ は, 給気圧を意味する. 供試燃料噴射率パターンを図 8 に示 す. 1 サイクルあたりの燃料噴射量を増やすには, 図 8 からわかるように燃料噴射期間を長引かせる方法をとっ た.したがって燃料噴射量を増やすと, 和栗の式 ${ }^{17)}$ から 
も明らかなように，燃料噴射終了時の噴霧到達距離が長 くなり, 噴霧内の空燃比は, 改善される方向にあるが, それだけピストンからの干渉も大きくなると想像される. 区 8 の二つの燃料噴射率パターンの場合燃料噴射終了時 の噴霧長さは, 燃料噴射量の多い方が少ない方より約 10 \%長くなる計算になる.しかしながら，図 $9 \mathrm{a}, \mathrm{b}$ 見る と燃料噴射量の違いによる $K_{\mathrm{e}}$ パターンの変化はほとん ごなく，特に燃焼後半は全く違いがないといえる.つま り実験範囲内での燃料噴射量の変化は, 燃料噴霧の燃焼 そのものに変化を与えなかったと言える．乙の現象につ いては二通りの解釈ができる. 一つは奏験範囲がせます ぎて，その効果を検出できなかったとする解釈であり， 他方は, 燃料噴霧はその大きさが異なっても, 自由に飛 行できる距離が同一ならば燃料の気化や周囲気体之の拡 散混合の程度がほぼ同一となり，その後の燃焼には違い が現れて来ないとする解釈である.ここに示した実験結 果からは，そのどちらとあ判断はできない. しかし 1 サ イクルあたり燃料噴射量が $6.6 \mathrm{~g}$ と $7.6 \mathrm{~g}$ では，あしてれ が同一軸出力であったとすれば燃料消費率に $10 \%$ 以上屯 差を生じることになる．燃費の差が $10 \%$ 以上ああれば図 3 之図 6 の比較からわかるように $K_{\mathbf{e}}$ パターンにあ大き い差が現れるはずである. しかし燃料噴射量がふえると 機関出力屯増大しており実測燃料消費率には大差なかっ た.このような経験から，乙こでは著者らは後者の解釈 をとっている．なお，図 9 から給気压 $P_{\mathrm{s}}$ は高い方が燃 焼が良くなるととがわかる.

\section{3. モデル装置による実験}

供試機関による実験の結果，燃料噴霧と燃焼室壁との 干渉が機関性能に大きな影響を及ぼすととがはっきりし た.との結果に対する理解をより容易にするため，モデ ル実験装置を使用して, 燃料噴霧と燃焼室壁の干涉の様 子を観察することにした.

3.1 実験装置と実験方法 実験装置の概要を図 10 に示す. 円筒型耐圧容器の中にピストン冠及びシリ ンダカバーに見立てた模型を傾けて入れた. 燃料弁は単 孔で, 円筒容器の上部に取り付けられ, 常に容器の軸上 を下方に向けて燃料を噴射する. 供試機関の実験因子の

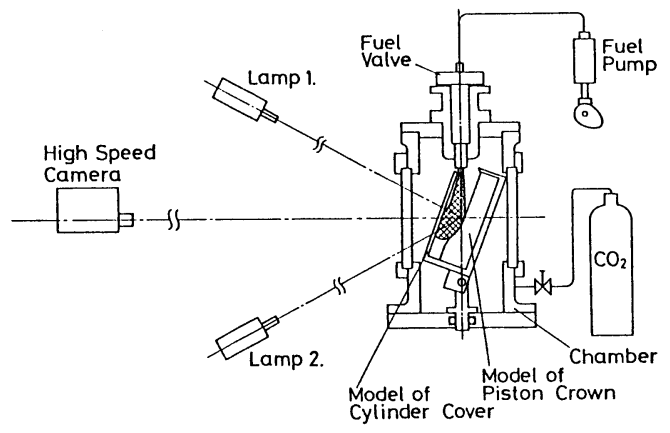

図 10 噴霧観察用モデル実験装置
一つである燃料噴射角を実現するには，燃焼室模型の傾 き角度を変えた. 円筒容器内には供試機関の王縮行程の TDC 状態のガス密度を再現するため炭酸ガスを 18 ata の圧力で充填した. 噴霧の成長の様子は, 高速度カメラ で撮影するととにより観察した. その際写真は，2 方向 から撮影した. 一つは，シリンダカバー側からピストン 冠に向かう方向であり, 図 10 はこの場合のカメラ配置 を示す. この撮影のため，シリンダカバーの模型は透明 アクリル板とした．他は，燃焼室断面方向の観察である. これは, 図 10 の燃焼室模型を耐圧容器の軸のまわりに 90 度回転させれば可能になる. 燃料弁は 1 回の写真撮 影に対して 1 回だけ噴射させた。

供試燃料系諸元は, 燃料弁開弁圧 400 ata, 最高燃料 噴射圧 $950 \mathrm{ata}$ (概数), 燃料噴射期間 $10 \mathrm{~ms}$, 噴孔径 0.61 $\mathrm{mm}$ あ゙ある. これを供試機関のあのと比較すると, 噴孔 径が $0.1 \mathrm{~mm}$ 小さい以外はほとんど差がない.

3.2 モデル装置による実験結果 四11a,b, c に 3 種の燃焼室形状の模型に対して燃料を噴射した場合 の，噴霧の成長の様子を示す. 各図とあ上側がシリンダ カバー側からピストン冠に向かって見たもの，下側が然 焼室断面方向に見たものである. 燃焼室断面方向に見た 写真では，左上方がシリンダライナ一軸部，右下方がラ イナー壁部に相当し，噴霧の右側の白い斜線はシリンダ カバーに見立てたアクリル板である. 噴霧の左側の白い 直線又は曲線は，ピストン冠を意味する，両者の間隔は 供試機関のTDC状態にあわせた.

図 $11 \mathrm{a}$ は, 図 2 の 1 型燃焼室に対するものである. 噴 霧は噴孔を出ると間もなくピストン表面に沿って這うよ うに成長している．噴霧の外形を見ると周期的に波打っ ており，(わゆる壁面噴流状態 ${ }^{15)}$ を呈している. てれは, 壁面との摩擦により噴霧の進行がさまたげられる結果で あろうと考えられ，壁面に凝縮する燃料油あ多いあのと 想像される.

図 $11 \mathrm{~b}$ は，図202 型燃焼室に対するあのである，噴 霧と壁面の衝突位置の噴孔からの距離は，1型燃焼室の 場合よりかなり遠くなっている，てれは，燃燒室容積を 一定にすると，シリンダ軸近傍で燃焼室高さが大になる ためである.しかし，ピストン面に衝突した燃料噴霧は， 大きくシリンダカバー側へまきあげられている. この現 象から，壁面へ衝突した時の噴霧はまだ充分前進能力を 持っているものの, 壁面から抵抗を受けてその運動量を 失ったものと考えられる. 燃料噴霧の横方向の広がり角 は，壁面亡衝突後，その位置加急に大きくなっている.

図 $11 \mathrm{c}$ は，図203 型燃焼室に対するあのである. シ リンダ軸近傍の燃焼室高さは，2 型燃焼室の場合よりさ らに大になる・したがって，燃料噴霧とピストンとの衝 突位置は，2 型燃焼室の場合よりさらに噴孔から離れた 所になっており，乙の燃焼室形状の場合が噴霧が最も長 く自由に運動できる.ピストン面に衝突した燃料噴霧は, 2 型然焼室の場合のようにまきあがることあなく，ピス 


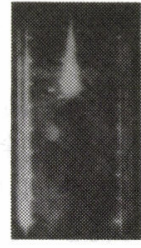

$0.98 \mathrm{~ms}$

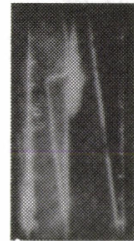

$0.91 \mathrm{~ms}$

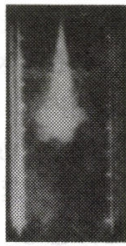

$2.09 \mathrm{~ms}$

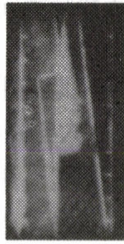

$1.97 \mathrm{~ms}$

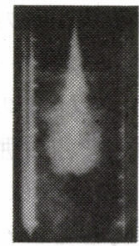

$2.99 \mathrm{~ms}$

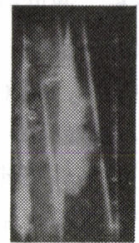

$3.03 \mathrm{~ms}$

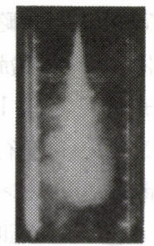

$4.10 \mathrm{~ms}$

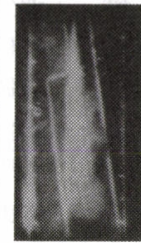

$4.09 \mathrm{~ms}$

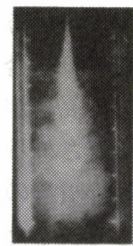

$4.99 \mathrm{~ms}$

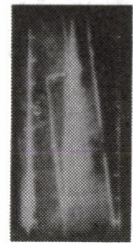

$4.94 \mathrm{~ms}$

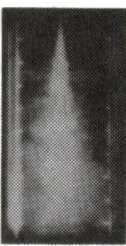

$0.11 \mathrm{~ms}$

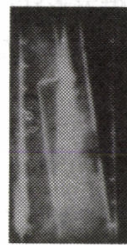

$6.00 \mathrm{~ms}$

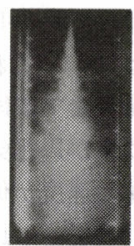

$7.00 \mathrm{~ms}$

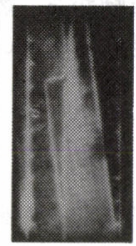

$7.06 \mathrm{~ms}$

図 $11 \mathrm{a} 1$ 型燃焼室内での噴霧の成長 (噴射方向角 7 度)

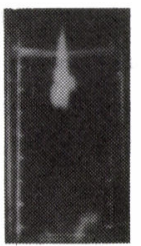

$0.96 \mathrm{~ms}$

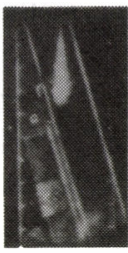

$0.93 \mathrm{~ms}$

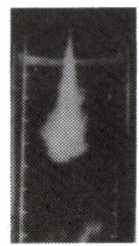

$2.06 \mathrm{~ms}$

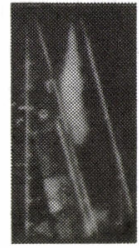

$1.98 \mathrm{~ms}$

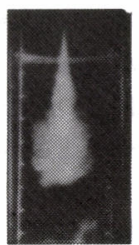

$2.94 \mathrm{~ms}$

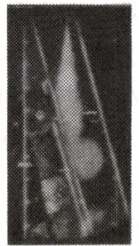

$3.04 \mathrm{~ms}$

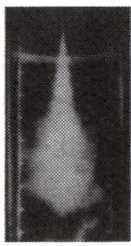

$4.04 \mathrm{~ms}$

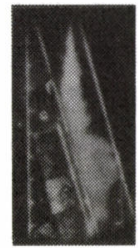

$4.09 \mathrm{~ms}$

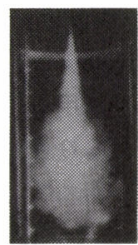

$4.92 \mathrm{~ms}$

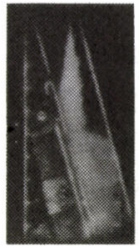

$4.94 \mathrm{~ms}$

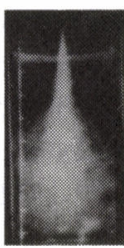

$6.02 \mathrm{~ms}$

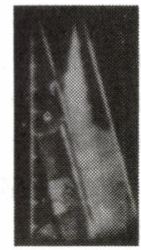

$5.99 \mathrm{~ms}$

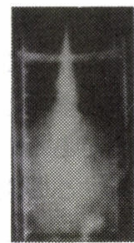

$6.90 \mathrm{~ms}$

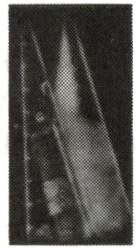

$7.05 \mathrm{~ms}$

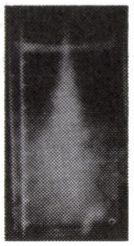

$8.00 \mathrm{~ms}$

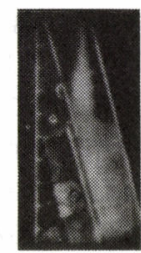

$8.10 \mathrm{~ms}$

1 目盛 $20 \mathrm{~mm}$

図 $11 \mathrm{~b} 2$ 型燃焼室内での噴霧の成長 (噴射方向角 15 度)

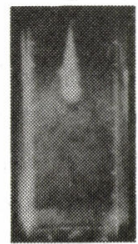

$0.98 \mathrm{~ms}$

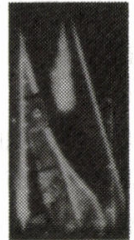

$1.04 \mathrm{~ms}$

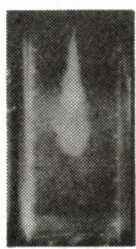

$2.11 \mathrm{~ms}$

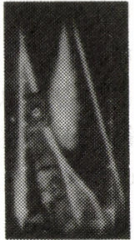

$1.93 \mathrm{~ms}$

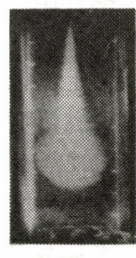

$3.93 \mathrm{~ms}$

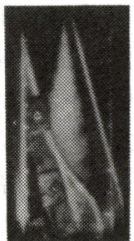

$3.05 \mathrm{~ms}$

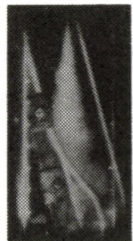

$3.94 \mathrm{~ms}$

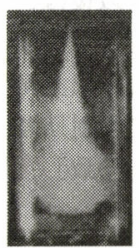

$5.06 \mathrm{~ms}$

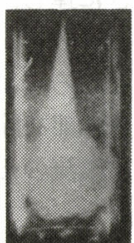

$5.97 \mathrm{~ms}$

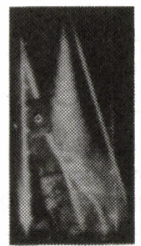

$5.95 \mathrm{~ms}$

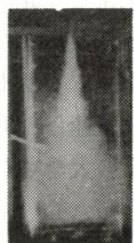

$7.11 \mathrm{~ms}$

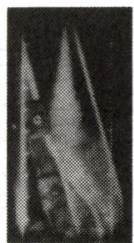

$7.06 \mathrm{~ms}$

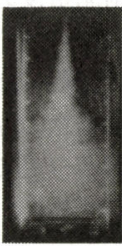

$8.02 \mathrm{~ms}$

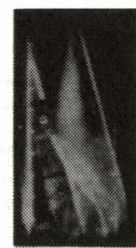

$7.96 \mathrm{~ms}$

図 $11 \mathrm{c} 3$ 型燃焼室内での噴霧の成長 (噴射方向角 15 度) 
トン面の形状に沿って移動しており, 衝突後の横方向の 広がりも極端ではない。乙れは，3 型燃焼室の場合は， 噴霧之壁面との衝突までに燃料之周囲気体の混合が充分 進み，燃料の運動量が周囲気体にかなり伝達されること によって燃料噴霧の速度が低下し, 衝突時の噴霧の前進 能力が 2 型燃焼室の場合に比較して減少しているためと 考えられる.

以上のモデル実験から，燃燒室形状の違いにより，燃 料噴霧が壁から受ける干涉の強さにかなり違いがあるこ とがわかった。

\section{4. 考察}

以上燃焼室の形状やその高さを変えて, 燃燒に対する 燃焼室壁の干渉効果を，主に $K_{\mathrm{e}}$ パターンを用いて調べ た. その結果, 燃料噴霧が噴孔から噴出した後, 壁の干 渉を受けずに自由に運動できる距離が長いか短いかが, 燃料噴霧の燃焼速度の速いか遅いかを大きく左右する之 考えられた.すなわち噴霧の自由飛行距離が長い場合程, 燃料噴霧の燃焼速度が高くなる. この結果は, 高速ディ 一ゼル機関に燃料噴霧と壁面との衝突干渉効果を利用し て，燃燒改善を図る例があるのに比較する之，かなり違 ったものになっている．乙の原因について考察を加えて みる.

まず著者らの研究室で画像解析法を応用し, 自由空間 に噴射された噴霧中の燃料濃度分布を実測した一例を図 $12^{16)}$ に示す. 図 12 では, 燃料濃度分布を 3 段階の空気 過剩率分布として示した. 乙の図から噴霧中の燃料濃度 は，噴孔出口に近いほどまた噴霧軸に近いほど高い之言 える. 松岡ら ${ }^{18)}$ の研究によると, この燃料噴霧の中心部 には，噴孔からある距離まで液柱が存在しているととが 報告されており，液柱の長さは噴射期間中のある時期以 後は，ほとんど変化しないとされている．著者らの実験 においても，空気過剩率が 1 より小さい部分の長さは， 噴射開始後ある時間で一定の長さに達し，それ以後は， 長くならないてとを見出している. 一方，田辺ら ${ }^{19)}$ が気 体の間歇噴流によって実測したととろによると，噴流軸 上の任意の位置の流速は，噴流先端部を除いて噴射期間 中ほぼ一定で, その大きさは定常噴流のそれと一致し，

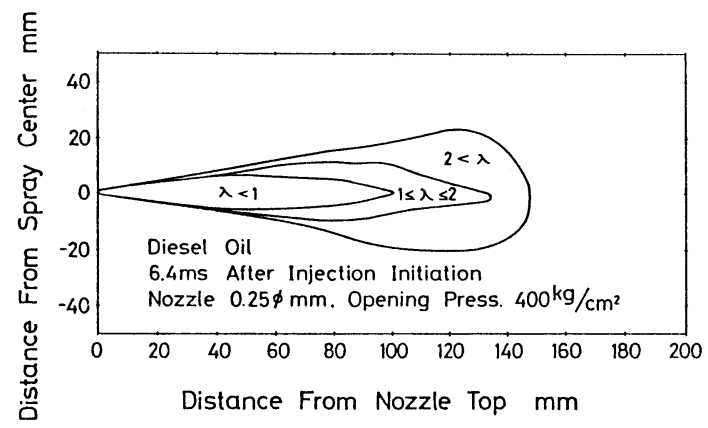

図 12 燃料噴霧中の空気過㮃率分布
大略噴孔からの距離に反比例する. また濃度分布も定常 噴流のそれに一致するとされている．乙れらの結果から 図 12 の $\lambda<1$ の範囲内には, 流速も高く燃料の微粒化が 進行中で, 周囲気体との混合の不完全な部分が存在し, $\lambda>1$ の領域は, 液体の蒸発が完了し周囲気体との混合 が進行している部分と考えられる. そして，噴射期間中 の液柱の長さがほとんど変化しないとと, 気体噴流の流 速分布, 濃度分布が喷流先端を除いて, 定常噴流のそれ にほぼ一致することから，著者らが実測したように $\lambda<1$ の領域は，噴射持続期間中ある一定の大きさを持ち， $\lambda$ >2の領域のみが拡大を続けることになる。一方, Witze $ら^{20)}$ の気体噴流に対する実測結果によると, 噴流中の任 意の位置の流速は，噴流がその位置に到達するとそれま での零から急激に有限の值を示すようになり，噴射終了 之同時に急激に減衰する，そしてての減衰は，噴流中の すべての位置で同時に起てり, また各位置における乱れ の強さも同時に減衰し始めると報告されている. 噴流中 の乱れの強さは, Johnston ${ }^{21)}$ によると周囲気体中の それよりはるかに強い。乙れらの実験結果から噴霧中の 燃料之周囲気体之の混合は, 噴射終了後は噴射持続期間 中に比べて，その速さがかなり低下するものと考えられ る.

このような燃料噴霧のイメージを使うと， $K_{\mathrm{e}}$ パター ンが図 9 のような形になるのは，つぎの様に説明される。 まず，燃焼初期は着火遅れ期間中に形成された可燃混合 気が，急速に燃焼するが，着火遅れ期間が短いとその量 は，燃焼室に存在する燃料の量に比べて少ないため $K_{\mathrm{e}}$ は小になる，その後燃焼の進行により燃焼室内の温度・ 珐力が上昇するととから，蒸発速度・反応速度が高くな り, 燃料噴射持続による活発なガス運動も加わって盛ん に燃焼し $K_{\mathrm{e}}$ を高める. 燃焼の後期には燃料噴射終了に よりガスの乱れ運動も減衰し，新気の燃焼域への取り入 れ速度が落ちて, 燃焼域の酸素濃度が低下する上に, 燃 焼域の拡大速度も落ちて， $K_{\mathrm{e}}$ が低下するもの之考えら れる。

以上の説明から，燃料喷霧の燃焼速度 $K_{\mathrm{e}}$ を高めるに は，燃料噴射期間中に燃料噴霧が持つ運動能力を最大限 有効に活かして，その期間中にできるだけ燃料と，周囲 気体との拡散混合を達成するととが重要であると言える.

ところで, 四11の写真からわかるように，1 型燃焼室 の場合は，噴霧は噴孔から噴出後すぐ壁面噴流の形にな っている. ての場合は，噴霧の流速が大きい時に壁面に 近づくため壁面での速度勾配が大になり, 噴霧は大きい 流動抵抗を壁面から受けて運動能力を急激に失うことに なる. その上に噴霧側面の円錐部之周囲気体之の接触面 積も減少して，そてから噴霧中に流入する周囲気体が減 るとと, 壁面に凝結する燃料量が增大し, 壁面による消 炎効果も大になるとと, 噴霧中の乱れなどのガス運動の 減衰が大きいととから，燃焼速度む落ちすすの排出量が 增大したものと考えられる，な押，国吉らによると，噴 
流中への周囲気体の流入量の内, 噴霧側面の円錐部から の量は, 全体の $25 \%$ 以上とされている.

3 型燃焼室の場合は, 噴霧内の流速が速い部分では噴 霧はほぼ自由空間にあり, 側面円錐部からの周囲気体の 流入も充分行われる. したがって, 噴流中の燃料と周囲 気体の混合が充分進行し, 噴霧の前進能力が低下してか ら壁面にあたるようになるため, 壁面での速度勾配は小 さくなり，流動抵抗む小になる.乙の場合は，壁面に凝 結する燃料もほとんどないと思われ，壁面から燃焼域へ の冷却効果も大きくないと考えられる. この結果 1 型燃 焼室に比較して，3 型燃焼室はかなり燃焼性能が良く， 2 型燃焼室は多くの点で両者の中間を行くことから，中 間の性能を示したものと思われる.

3 型燃焼室の高さを変えて行った実験の結果で, 高さ の $K_{\mathrm{e}}$ パターンに及ぼす影響に対する解釈む, 上に述べ た燃焼室形状変更試験の場合と全く同じ理由で説明され る.また, 燃料噴射量を変えた実験では, 先に述べた噴 霧のイメージを用いると, やはり噴霧の自由飛行距離が 同じであれば，多少噴射期間が増大あしくは短縮しても， 燃焼に影響しないと解釈する著者らの考えで理解してよ いと考える.

なお，3型燃焼室で噴射方向 15 度より 19 度, 23 度の 方が性能がよいのはピストンとの衝突後の噴霧の運動方 向も，多少性能に影響することを示すものである. この 点については著者らは，文献 9) の解釈と同意見である.

\section{5. を め}

中速ディーゼル機関を用いて燃焼室の形状を変え, 燃 料噴霧の燃焼がごんな影響を受けるかを実験的に調べ， 考察を加えた. その結果, 燃料噴霧が噴孔から噴出した 後,できるだけ長い期間, 壁の影響を受けず自由に運動 できるような形状の燃焼室の方が燃料噴霧の燃焼速度が 高く, 機関性能 (燃料消費率, 排煙濃度など) が良いとと が明らかになった：てれは燃焼速度を高める第一条件で ある周囲気体と燃料之の混合が, 燃料噴霧自身が持つ周 囲気体に対する相対運動能力によって達成されると考え られるととを示しており，乙の噴霧の運動能力をできる だけ長期間温存できる形状の燃焼室が，良好な機関性能 を示したものと解釈できる.

中速ディーゼル機関では, 燃焼室形状はとかく偏平に なりがちであるが, この実験の結果から，燃焼室を設計 するための一つの指針が得られたものと考えられる。

\section{文献}

1) 国吉 光, 慶応大学博士論文 (1977).

2) Lustgarten, M T Z 35 (1974) 9273.

3）常本・ほか 2 名, 第 3 回内燃機関合同シンポジューム予 講集 $(1982) 73$.

4) 広安·ほ加 2 名, 機論, 46-403(1980)531.

5）堀・ほか 2 名, 機講論, $760-7$ (1976) 57 .

6) 堀・ほか 2 名, 機講論, $770-4$ (1977) 34 .
7) 長尾・ほ加 4 名, 機論, 38-311(1972)1866.

8) 長尾・ほか 4 名, 機論, 38-311(1972) 1875 .

9）長尾・ほか 3 名, 機論, 39-324(1973)2539.

10）神本・ほか 3 名, 機論, 46-403(1980) 540 .

11）神本·ほ加 3 名, 機論, 47-414(1981)392.

12) M. Kawakami・ほか 2 名, ISME ' 83 Technical Paper (1983) 303.

13）下津・ほか 1 名, 機論, 47-418(1981) 1135 .

14）下津・ほか 3 名, 機論, 51-461, (昭 60), 232.

15）菱田・ほか 1 名, 機械の研究, 35-11(1983)24.

16）坂根 · ほか 3 名, 機械学会第 62 回全国大会予稿集 (1984).

17) 和栗·ほか 3 名, 機論, 25-156(1959) 820 .

18）松岡・ほか 1 名, 第 3 回内燃機関合同シンポジューム予 講集 (1982) 85 .

19）田辺・ほか 5 名, 機講論, 848-2(1984)97.

20) P. O. Witze, AIAA Journal 21-2 (1983) 308.

21） S. C. Johnston •ほか 4 名, SAE Paper 790092 (1979).

（付録） $K_{\mathbf{e}}$ の計算方法 文献 13)に詳しいので，概 要のみを記す．燃料噴射開始及び燃焼開始のクランク角 をそれぞれ $\theta_{\mathrm{I}}, \theta_{\mathrm{C}}$ とし，任意のクランク角を $\theta$ とする. 時刻 $\theta$ で燃焼室に残る未燃燃料の質量を $f$ とする. 燃料 噴射量及び熱発生量をそれぞれ $W ， Q$ で表し，1 サイク ルあたりのそれらを $W_{\mathrm{T}}, Q_{\mathrm{T}}$ 亡すると次式が成立する.

$$
f=\int_{\theta_{\mathbf{i}}}^{\theta} \frac{d w}{d \theta} d \theta-\frac{W_{\mathrm{T}}}{Q_{\mathrm{T}}} \int_{\theta_{\mathrm{C}}}^{\theta} \frac{d Q}{d \theta} d \theta
$$

燃料の低位発熱量を $H_{\mathrm{U}}$ とすると, 1 サイクルあたりの理 論熱発生量は $W_{\mathrm{T}} \cdot H_{\mathrm{U}}$ となる. これに対する $Q_{\mathrm{T}}$ の割合 を利とすると， $W_{\mathrm{T}} / Q_{\mathrm{T}}=1 /\left(\eta_{\mathrm{C}} H_{\mathrm{U}}\right)$ となる。 また，基 準温度での燃料油の密度を $\rho$ とし, $f$ を 1 個の滴と仮想 した場合の径を $D$ とすると， $f=\pi \rho D^{3} / 6$ となる. これ らを上式に代入し，両辺を $\theta$ で微分して整理すると，

$$
\frac{d D^{2}}{d \theta}=\frac{4}{\pi \rho D} \frac{d W}{d \theta}-\frac{4}{\pi \rho \eta_{\mathrm{C}} H_{\mathrm{U}} D} \frac{d Q}{d \theta}
$$

となる.乙の式の右辺第 1 項は, 燃料噴射による仮想滴 の膨張速度を，第 2 項は燃焼による収縮速度を表す。 こ の第 2 項に $\eta_{\mathrm{C}}$ をかけて, その結果を時刻 $\theta$ での $K_{\mathrm{e}}$ とす る.

$$
K_{\mathbf{e}}=\frac{4}{\pi \rho H_{\mathrm{U}} D} \frac{d Q}{d \theta}
$$

この式の右辺は, 準定常理論による単滴の燃焼速度係数

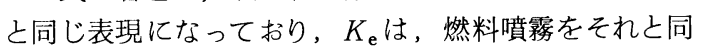
一の未燃質量をもつ単滴に仮想した場合の燃焼速度係数 と考えられる. $K_{\mathbf{e}}$ の物理的意味については，文献 13) にて考察したが, 簡単にはつぎのように考えられる. 基 準温度, 大気圧状態で質量が $f$ の単滴の燃焼速度係数を $k$ とおく. $X_{\mathrm{e}}=K_{\mathrm{e}} / k$ で $X_{\mathrm{e}}$ を定義すると, それは然料 を高温高圧雾囲気中へ微粒化して吹き込むてとにより， 基準状態下で 1 滴として燃焼させるよりどれだり大きい 燃焼速度が得られるかを意味する. したがって， $X_{\mathbf{e}}$ は $f$ の值には関係せず, 燃料噴霧の物理的化学的状態, たと 
えば雾囲気のガス運動状態の適不適，燃料の分散度，微 粒化の程度など燃料噴霧を特性づける多くの因子の影響 を反映するもの之考えられる，一方 $k$ は，燃料の燃焼性 をあらわしており，実験的に $f$ の值に関係しないてとが わかっている.したがって， $K_{\mathrm{e}}=X_{\mathrm{e}} \cdot k$ 之考えるとと により $K_{\mathrm{e}}$ は燃料の燃焼性をふくむ燃料噴霧の燃焼その あのを，直接評価する強度因子であると解釈するととが できる.

\section{〔質 疑 応 答〕}

質問者 北見工業大学 常本秀幸

〔質問〕 とくに燃焼状態と噴霧との間の関係を実験的 かつ理論的にも評価するなど興味深く拝見させて頂きま した.さて，いくつか質問がでざいますのでで教示願え れば幸いと存じます。

1）貴論文の実験結果に拈きましてては, 燃料噴射時期 の影響には触れられておりませんが, 1 3 型の燃焼室の 結果はすべて同一の噴射時期で得られたものでしょうか. あし，そのような場合であれば，噴射時期を変えると之 によってノズル位置とピストンとの距離 (噴霧の運動長 さ)が変わり，例えば 1 型の燃焼室であっても燃費ある いは吐煙が改善される可能性はないでしょうか.

2）図 3 亿おきまして, 各タイプの燃燒室では燃費及 び吐煙の面からほぼ 9 孔のノズルによって良好な值が得 られておりますが, とくに噴霧挙動の上から，その理由 はどのように考えれば宜しいでしょうか.

3）熱発生率曲線図 $4 \mathrm{a} \sim 4 \mathrm{c}$ 及び $K_{\mathrm{e}}$ 線図 $6 \mathrm{a} \sim 6 \mathrm{c}$ は, 同様の比較をしているととになりますが， $K_{\mathrm{e}}$ 線でなけ れば評価できない部分はどのような点でしょうか.

4） 1 型燃焼室の性能が悪い原因を噴霧が早期に壁面 に付着したためと説明されておりますが，M燃焼室のよ うに積極的に付着させる場合もあります。この点から考 えると，1型では燃焼室内における空気の質量分布之燃 料の質量分布が適切でないととも原因と考えられますが いかがでしょうか.

〔回答〕1）図6 までに結果を示す実験は, バルブタ イミング, TDC時燃佬室容積, 給気圧, シリンダ背圧, 機関回転数， $P_{\mathrm{i}}$ をそろえた上で，燃焼最高圧が 131.03 a taになるように燃料噴射時期を調節しながら行った.

したがって, 燃焼室形状によって, 燃料噴射開始時期は 少しずつ違っている. 1 型では $165 \sim 168^{\circ} \mathrm{CA}-\mathrm{ABDC}$ の 間，3型では $168 \sim 170^{\circ} \mathrm{C} \mathrm{A}-\mathrm{ABDC}$ の間である. この程 度の時期の相違は, 同じピストンならば, 乙の時期の燃 焼室の高さを $5 \mathrm{~mm}$ 程度変化させる. しかし, 燃料弁近 傍では, ピストン冠の形状の違いによる高さの差の方が これより大きい。また，燃料噴射期間は， $30^{\circ} \mathrm{C} \mathrm{A}$ 位あり， 燃料噴射期間は，TDCの前後にまたがる，したがって 1 型の燃焼室で壁の影響を軽減しようとすると，かなり $\mathrm{TDC}$ 時の燃焼室容積を大きくする必要があり，実験目
的の範囲外になるので，実験していない．

2）むずかしいで質問で確実なで解答は致しかねる. 9 孔では，噴霧 1 本あたり 40 度の角度が割りあてられ る. 噴霧円錐角は 20 度程度までと考えられるから，噴 霧により, 燃料弁からライナ一方向へ向かう流れが 20 度を占有し，その噴霧の進行によって，周囲に誘起され るガス運動にも 20 度程度の角度が割りあてられる. こ の雨方に同じ程度の角度が割りあてられるのが, スワー ルのない場合の空気利用率から考えて, バランスがよい というととかと推定している．諸先生方の抄えをお䫌 いします。

3）熱発生率は, 值そのものが, 燃焼室に存在する未 燃燃料の質量が多くなれば大きくなるという容量性因子 であるから，燃料噴射開始後その終了までは熱発生率が 大きくなり，噴射終了後は漸減するといったパターンは， いつの場合にも見られる. 従来のような熱発生パターン による燃焼の比較は, 乙の熱発生率の増大や減少の勾配 もしくは，それから計算される熱効率による比較が主で， 燃料噴射側の挙動を考慮しないサイクル論的な側面が強 いものであった．乙れに対し， $K_{\mathrm{e}}$ パターンは強度因子 であるため, 燃焼期間中のぞの時点で燃焼そのものの差 がどの程度あるかといった細かな，定量的な比較ができ る. そのため, 実験因子の噴霧燃焼に及ぼす影響につい て考察しやすい資料となる.

4) M燃焼法に限らず, 最近の直噴型高速ディーゼル 機関も燃焼室壁に噴霧を付着させているととは認識して いる. これらと 1 型燃燒室の相違点として, 空気分布に 対する付着点の位置の問題があげられる. 前者の場合は, いずれも噴霧が壁に衝突し，燃料は強いスワールに乗っ て横方向へ移動することによって, 燃料の微粒化と分散 を改善する．そして，空気は付着点より燃焼室中心側に 大部分が存在しているから，スワールの熱ピンチ効果等 を考えあわせると，燃焼期間中にも空気利用率の向上が 期待できる.

一方， 1 型燃焼室の場合は，噴霧と壁のなす角度が非 常に小さい。しかも, 空気の分布は, 付着点よりさらに 遠方の方がはるかに多い。乙の遠方にある空気を利用す るには，噴蓩自身の運動能力に期待するしかないが，壁 に付着した噴霧はその能力を急激に失ない，遠方への到 達が困難になる。

てのようなととから，で指摘のように，1 型の場合は 燃料之空気の分布の仕方が不適切になったもので，その 程度が噴霧の付着により強調された之解釈している. 質問者 阪神内燃機工業(株）堀 雄一

〔質問〕 5 頁の図 $7 \mathrm{a}$ と $7 \mathrm{~b}$ を見ると $7 \mathrm{a}$ の方が噴射角 度が小さく，噴霧の自由運動空間が多いにもかかわらず， $K_{\mathrm{e}}$ 值は少なくなっている.

結論のとてろで述べられているととを相違していると 思うが如何.

〔回答〕噴射角度 11 度は，噴霧円錐角を考虑すると， 
静的にはシリンダカバーとは 1 2 度しかあいていない. 一方文献 9)の池上らの報告では, 噴霧がピストン上昇 上共に上方に押し上げられる現象が指摘されている. こ れらから著者らは，で指摘の図 $7 \mathrm{a}$ では，噴霧が噴射期 間中にシリンダカバーに触れ，それに沿って成長し燃焼 したあのと解釈している. 図 $7 \mathrm{a}$ と bを比較して, a の場 合には，燃料噴射期間の中期から末期にかけて $K_{\mathrm{e}}$ に盛 り上りがないてとが，乙のととを示唆しているものと思 う.

質問者 同志社大学工学部 藤本 元

〔質問〕 1）図 $9 \mathrm{a}$ )〜 b)〜 c)では噴射期間一定にし て熱発生率を比較すべきと思いますが如何.

2）燃焼室高さを変化させた実験では圧縮比一定でし ょうか.

3）噴射率を変化させた実験では図 8 の如く噴射終了 で制御されている. したがって噴霧の条件は $W_{\mathrm{T}}=6.6$ と $W_{\mathrm{T}}=7.7$ では後者は約 $25^{\circ} \mathrm{CA}$ まで前者と全く同じ経過を たどるはずである. あちろん衝突までの時間, 飛行距離 の問題があるが, 図 $9 \mathrm{~b}$ で然焼の前半で $K_{\mathrm{e}}$ が異なるのは どのような理由によるのでしょうか.

4）図 12 は直接写真によるのでしょうか. ある時間 で $く<1$ の部分が一定になるとありますが，てれは噴射 側の条件例えば, 噴孔径, 噴射角度等によらず一定なの でしょうか。

〔回答〕1）著者らの実験の目的は，機関出力を保証 した上での燃費の改善であり，したがって，で指摘のよ うに噴射期間を一定にしようとすると，燃料噴射率を実 験でとに変えなくてはならない。噴射率自体は燃焼に対
して重要な影響を持つ因であるとの認識から，今回は 噴射率を一定にした実験を行った.したがって機関性能 の良否により，1サイクルあたりの燃料噴射量や噴射期 間が異なった. これらの変化は熱発生率パターンを変化 させることはご指摘のとおりで，その影響をできるだけ 小さくする燃焼判定因子として， $K_{\mathrm{e}}$ を使用した。

2) 機関の静的な圧縮比は, 吸気弁閉時期を変更して 同一になるようにした. また, 給気温度と圧力を変化さ せて, シリンダー内ガス量あ同一にした. したがって， この実験では, 燃焼最高圧は実験ごとに異なる.

3）困 9 の実験は,ご指摘のような理由から少なくと も燃焼前半は同じ $K_{\mathrm{e}}$ パターンになると考えて行った. 本報に示した実験結果の中で，そのような結果を予め

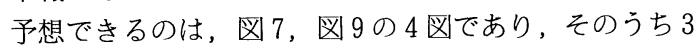
図まではての予想を支持している。燃焼の前期は初期燃 焼による王力波の発生などから，図４亿示すように実測 の熱発生率の時間変化が大きく，計算機によってそれ を平滑して $K_{\mathbf{e}}$ 值を計算する場合の平滑化の程度に問題 が残る. 図 $9 \mathrm{~b}$ の場合も主として，その辺の影響であ る.

4）透過光による直接写真を画像解析により処理して, 噴霧中の燃料濃度分布を求め, それを同一の条件で撮影 した 10 枚の写真について平均したものである. $\lambda<10$ 部分の大きさは, 著者らの実験と, 松岡らの実験(文献 18))で異なっており，噴孔径等，噴射系因子の影響を受 けるものと考えられる．著者らの実験の詳細については， 文献 16)を参照されたい. 